\title{
THE EFFECT OF FUNDING AND INVESTMENT DECISIONS TOWARD COMPANY VALUE WITH DIVIDEND POLICY AS THE INTERVENING VARIABLE ON MANUFACTURING SECTOR LISTED IN INDONESIA STOCK EXCHANGE
}

\author{
Putri Nyayu Khairani*, Student \\ Management Science Master Program, Sriwijaya University, Indonesia \\ Isnurhadi, Yuliani, Hanafi Agustina, Lecturers \\ Department of Management Science, Sriwijaya University, Indonesia \\ *E-mail: nyayukhairani@yahoo.com \\ ORCID: 0000-0002-4176-0423
}

\begin{abstract}
Company value reflects the current value of the desired revenue in the future and the indicator for the market in assessing the company holistically. Implementing the financial management function is the way that can be done to achieve the company's objectives. The optimal combination of management decision can optimize company value that will affect shareholder wealth. The funding decision is a very significant decision for the company because it involves the acquisition of funding sources for operational activities and to finance the company's investment activities. In this case, funding decision and investment decision are interconnected. Funding sources within the company can be obtained from inside or outside the company.
\end{abstract}

\section{KEY WORDS}

Funding decision, investment decision, dividend policy, company.

An institution in establishing a company should have clear goals. The company goals are such as gaining maximum profit, willing to make company owner welfare, and optimizing company value that can be seen from its share price. Company value reflects the current value of the desired revenue in the future and the indicator for the market in assessing the company as a whole. Implementing the financial management function is the way that can be done to achieve the company's objectives. The optimal combination of management decision can optimize company value that will affect shareholder wealth.

The market value of a company equity added with the market value of the debt is the value of the company in which the addition of debt from the amount of equity can then reflect the value of the company. Based on Cretu and Brodie (2007) research, there are several factors that can affect the value of the company, including: investment decision, funding decision, dividend policy, company growth, company size, profitability, and institutional ownership. Some of these factors have a relationship and effect on inconsistent corporate values.

The funding decision is a very significant decision for the company because it involves the acquisition of funding sources for operational activities and to finance the company's investment activities. In this case, funding decision and investment decision are interconnected. Funding sources within a company can be obtained from inside or outside the company. Funds from inside the company are called retained earnings and funds from outside the company are called debt.

Based on the research of Sartini and Purbawangsa (2014), it shows that funding decision has a significant positive effect to company value. The research result conducted by Fenandar and Raharja (2012) on the contrary states that funding decision does not have significant effect to company value. Another decision related to company value is investment decision. Investment decision are the decision that reflects future investment opportunities, ie through the introduction of new products or the expansion of old products, replacement of 
equipment or buildings, research and development, and exploration. The implication for company is the company must plan to make investment decision through the introduction of new products or the expansion of old products, replacement of equipment or buildings, research and development as well as exploration (Husnan, 2008).

The research regarding the impact of investment opportunity set on the company value has been done by Hasnawati (2005). Investment opportunity that will generate value in the future will be greatly influenced by the investment made by the company. The results of this study succesfully finding high IOS value is proven to have high company value in the current period and in the upcoming period.

Another policy related to company value is dividend policy. The dividend policy is an intervening factor in this present study. The ability of company to pay dividends may reflect the company value. If the dividend payout is high, then the stock price is also high which affects the high company value as well. Thus, dividend policy is one of the most important decisions. In this present research, dividend policy is measured by dividend payout ratio. Diana and Fitria (2017) find that investment decision has positive effect to dividend policy.

Based on the above explanation, the objectives of this study are: 1) to explain the funding decision and investment decision directly on the company value in manufacturing company listed on the Stock Exchange period of 2013-2016. 2) to explain the effect of funding decision and investment decision to company value with dividend policy as the intervening variable at manufacture company listed on Indonesia Stock Exchange year of 2013-2016.

\section{LITERATURE REVIEW}

Signalling Theory. Mogdiliani and Miller assume that investors and managers have the same information about the prospect of a company called symmetric information. However, in fact, the manager has more information about the company than the investor. This is called asymmetric information where it can affect the optimal capital structure. Signaling theory is a settlement of information asymmetry (Alivia, 2013).

Trade-Off Theory. This theory discusses the relationship between capital structure and company value. Trade-off model assumes that the capital structure of the company is the result of the trade-off of tax profits by using debt with the cost of which is reflected as a result of the use of the debt. The trade-off theory essence in the capital structure is to balance the benefits and sacrifices arising from the use of debt. As long as benefits are greater, additional debt is still permissible. The sacrifice of the debt because of the greater use of debt, the additional debt is not permitted.

Bird in the Hand Theory. This theory is proposed by Myron Gordon (1959) and John Lintner (1956) who argue that equity or company value will decrease if the dividend payout ratio is lowered as the investors are less confident of capital gains generated from retained earnings than if investors receive dividends. Gordon and Lintner state that investors are much more appreciative of the expected earnings of dividends than the expected income from capital gains.

Company Value. Company value is the price that the prospective buyer is willing to pay when the company is sold (Husnan, 2008). The company value is often associated with the stock price. The higher the stock price, the higher the company value will be (Brigham and Houston, 2007).

Funding Decision. Funding decision is a decision on the source of funds that will be used by the company. The source of funds is divided will be able to affect into two, namely internal fund source and external fund source. External fund source used by company is debt and capital. To determine the optimal composition of funding that the company value. This ratio shows the comparison between financing and funding through debt with funding through equity.

Investment Decision. Investment decision is the decision regarding investment to gain profits or benefits that are acceptable. According to Gaver and Kenneth (Hasnawati, 2005) Investment Opportunity Set (IOS) is the value of a large company depending on the expenditures that are determined by the management in the future period in which the 
investment option is expected to produce large returns. The selected IOS option is the ratio of market to book of asset (MBVA).

Dividend Policy. Dividend policy is the decision whether the profits earned by the company will be distributed to shareholders as dividends or will be held in the form of retained earnings in order to finance future investment. If the company chooses to distribute profits as dividends, it will reduce the retained earnings and subsequently reduce the total internal financing sources (Sartono, 2001).

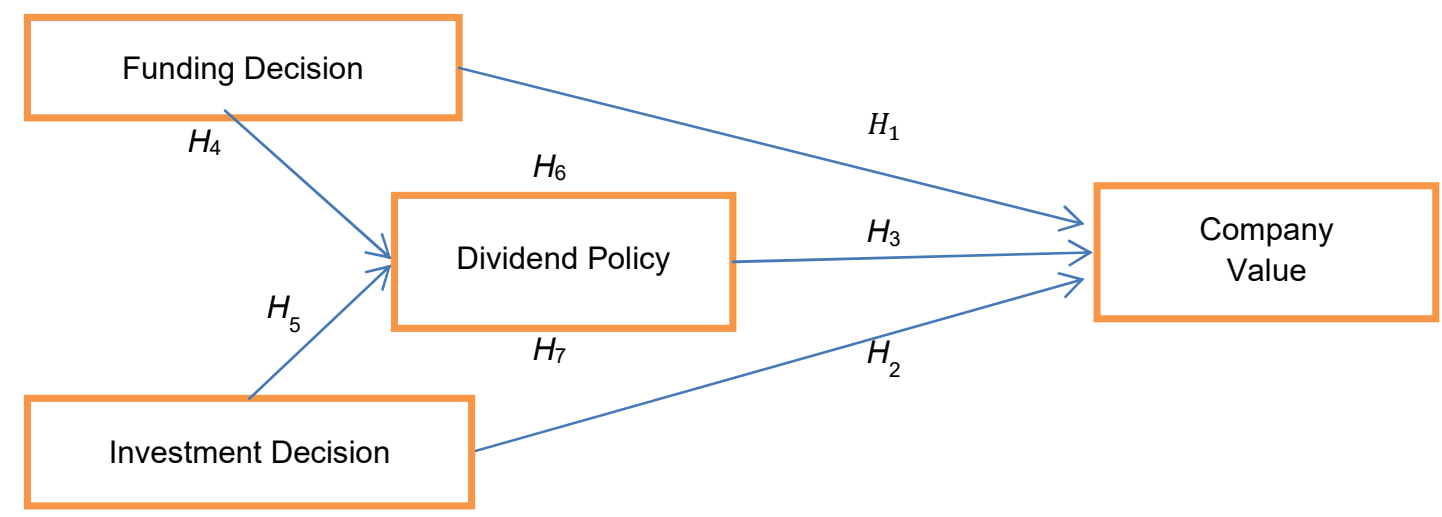

Figure 1 - Model of Research Hypothesis

Research Hypotheses:

- $\mathrm{H}_{1}=$ Funding decision affects company value significantly;

- $\mathrm{H}_{2}=$ Investment decision affects company value significantly;

- $\mathrm{H}_{3}=$ Dividend policy affects company value significantly;

- $\mathrm{H}_{4}=$ Funding decision affects dividend policy significantly;

- $\mathrm{H}_{5}=$ Investment decision affects dividend policy significantly;

- $\mathrm{H}_{6}=$ Dividend policy is able to mediate funding decision towards company value;

- $\mathrm{H}_{7}=$ Dividend policy is able to mediate investment decision towards company value.

\section{METHODS OF RESEARCH}

The populations in this study are all manufacturing companies listed on the Indonesia Stock Exchange (IDX) according to the Indonesian Capital Market Directory (ICMD) publication in the period of 2013 to 2016 as many as 150 companies.

The sampling is based on the purposive sampling method. The sampling process utilizes criteria from the list of manufacturing companies listed in Indonesia Stock Exchange (IDX) in 2013-2016 amounted to 50 companies with the observation total of 200 (50 companies $x 4$ years).

The data used in this study is secondary data in the form of company financial statements in the period of 2013 to 2016.

The data collection technique used is documentation in which the data are collected from annual financial report of company and company annual report with period of five years starting from 2013 to 2016 . The step undertaken is by recording all data needed in research to calculate DER, MBVA, PBV, DPR which will then be analyzed.

This study will present the average statistics that are supplemented with the highest and lowest values in each variable of funding decision, investment decision, company value, and dividend policy.

Inferential statistics in this study utilizes path analysis. Path analysis is an extension or development technique of multiple linear regression analysis. This study uses the application program of Statical Product and Service Solutions (SPSS) version 23 to help analyze data in this research. 
Table 1 - Operational Definition

\begin{tabular}{|c|c|c|c|c|}
\hline No. & $\begin{array}{l}\text { Research } \\
\text { Variables }\end{array}$ & Operational Definition & $\begin{array}{l}\text { Measurement } \\
\text { Scale }\end{array}$ & Indicator/Formula \\
\hline 1. & $\begin{array}{l}\text { Funding } \\
\text { Decision }\left(\mathrm{X}_{1}\right)\end{array}$ & $\begin{array}{l}\text { Funding Decision is a comparison between } \\
\text { financing and funding through debt with funding } \\
\text { thhrough equity. }\end{array}$ & Ratio & $\begin{array}{l}\text { Debt to Equity Ratio = } \\
\frac{\text { Debt Total }}{\text { Equity Total }}\end{array}$ \\
\hline 2. & $\begin{array}{l}\text { Investment } \\
\text { Decision }\left(X_{2}\right)\end{array}$ & $\begin{array}{l}\text { It is greatly influenced by the company's } \\
\text { investment opportunity which is the company's } \\
\text { ability to exploit the opportunity to take } \\
\text { advantage. This opportunity is unobservable }\end{array}$ & Ratio & $\begin{array}{c}\text { MBVA }= \\
\text { Activa Total -Equity Total } \\
+(\text { shares distributed } \\
\text { x closing price }) \\
\text { Asset Total }\end{array}$ \\
\hline 3. & Company & $\begin{array}{l}\text { except for certain proxies. } \\
\text { It is commonly indicated by the stock price } \\
\text { which is the ratio of the market value of a stock }\end{array}$ & Ratio & $\begin{array}{l}\text { Asset Total } \\
\begin{array}{c}\text { Price Book Value }= \\
\text { Share Market Price }\end{array}\end{array}$ \\
\hline & Value (Z) & $\begin{array}{l}\text { to the book value of the company so that it can } \\
\text { measure stock price level. }\end{array}$ & & $\overline{\text { Book Value per shares }}$ \\
\hline 4. & $\begin{array}{l}\text { Dividend } \\
\text { Policy }(\mathrm{Y})\end{array}$ & $\begin{array}{l}\text { It is the company's decision regarding the } \\
\text { policy relating to the determination of the } \\
\text { percentage of net profit of the company which } \\
\text { is distributed as dividend to the shareholders. }\end{array}$ & Ratio & DPR $=\frac{\text { Dividend Per Share }}{\text { Earning Per Share }}$ \\
\hline
\end{tabular}

Source: Processed from several journals.

\section{RESULTS OF STUDY}

Linearity Test. The linearity test is conducted to know whether the model is accurate in describing the relationship between the variables being studied and can be considered as a good model. One of the assumptions in the regression is that the relationship between the dependent variable and the independent variable is linearly related (Supriyadi, 2014).

Table 2 - Result of Variable Linearity Test

\begin{tabular}{|c|c|c|c|c|}
\hline Independent Variable & Dependent Variable & Test Result $(\alpha=0.05)$ & Sig. & Decision \\
\hline DER & DPR & All model is significant & 0.000 & Linear \\
\hline MBVA & DPR & All model is significant & 0.000 & Linear \\
\hline DER & PBV & All model is significant & 0.001 & Linear \\
\hline MBVA & PBV & All model is significant & 0.000 & Linear \\
\hline DPR & PBV & All model is significant & 0.005 & Linear \\
\hline
\end{tabular}

Source: The data is analyzed by the researcher.

The approach used is Curve Fit in which the decision rule refers to the concept of parsimony, that is, when all models used as the basis of testing are significant or not significant or linear function is significant, it means that the model is considered being linear.Table 3 reveals that all forms of relationships between variables in the structural model is linear. Hence, the assumption of linearity in this structural model has been fulfilled.

Goodness of Fit Model Test. The result of goodness of fit model test can be fulfilled if it is supported by the calculation of valid data. Goodness of fit structural model on the analysis is in the form of total determination coefficient value $\left(R^{2} \neg \mathrm{m}\right)$. This value is calculated based on $R^{2}$ value of each dependent variable. From the results of data processing, it is found that the values of $R^{2}$ dividend policy and $R^{2}$ value of the company value are 0.446 and 0.789 . Based on $R^{2}$, each dependent variable can be calculated, thus, the value of predictiverelevance can be calculated $\left(Q^{2}\right)$ :

$$
Q^{2}=1-\left(1-R_{1}{ }^{2}\right)\left(1-R_{2}{ }^{2}\right)\left(1-R_{3}{ }^{2}\right)=1-(1-0,446)(1-0,784)(1-0,326)=0,92
$$

The value of $Q^{2}$ obtained is of 0.92 which can be interpreted that the model used to predict the endogenous variable is appropriate to be used as the basis for hypothesis testing. The value of the total determination coefficient of $92 \%$ is a good value and accurate to predict the company value, the remaining $8 \%$ is not included in this research model. below.

Hypothesis Testing Result. The research hypothesis result is presented in the table 3 
Table 3 - Research Hypothesis Testing Result

\begin{tabular}{llllll}
\hline Independent Variables & Mediating Variables & Dependent Variables & Coefficient Path & $p$-value & Detail \\
\hline DER & & PBV & 0.200 & 0.000 & Significant \\
MBVA & & PBV & 0.866 & 0.000 & Significant \\
DPR & & PBV & 0.326 & 0.000 & Significant \\
DER & DPR & -0.276 & 0.000 & Significant \\
MBVA & DPR & 0.237 & 0.002 & Significant \\
DER & PBV & 0.111 & 0.003 & Partial Mediation \\
MBVA & PBV & 0.943 & 0.007 & Partial Mediation \\
\hline
\end{tabular}

Source: it is processed by the researcher; significant on $=5 \%$; Detail: DER: funding decision; MBVA: investment decision; DPR: dividend policy; PBV: company value.

\section{DISCUSSION OF RESULTS}

Funding Decision Positively and Significantly Affects Company Value. The result of regression analysis is obtained that Hypothesis $1\left(H_{-} 1\right)$ is accepted with positive regression coefficient; therefore, it can be concluded that funding decision has positive and significant effect to company value so that the increase of funding decision hence will be followed by the increase of company value. It is in line with the trade-off theory that predicts a positive relationship between capital structure and company value with the assumption of tax benefit is still greater than the cost of bankruptcy and the cost of the agent. In essence, the trade-off theory shows that the value of a company with debt will increase with increasing debt levels. The use of debt will increase the value of the company but only at a certain point. After that point, the use of debt actually lowers the company value.

High debt indicates a high level of risk. In the capital structure theory, the capital structure policy involves balancing the risk and the rate of return that is by using more debt which means it will increase the risk borne by shareholders but using more debt can also enlarge the rate of return that investors expect. In accordance with risk and return theory, the higher the risk level of a company, the greater the return expected by the investor. If higher risks are not matched by high returns, then there will never be investors who are willing to invest in the company. The return of a company can be either a dividend or a capital gain. However, based on the bird-in the hand theory, investors prefer dividends to capital gain.

The conclusions obtained from Antwi, et al (2012), Arifah and Roifah (2013), Sartini and Purbawangsa (2014) state that funding decision has a significant and positive effect on company value. The same results are also obtained in the study, namely funding decision has a significant and positive effect on company value.

Investment Decision Positively and Significantly Affects Company Value. The result of regression analysis obtained shows that Hypothesis $2\left(\mathrm{H}_{-} 2\right)$ is accepted with marked positiveregression coefficient. It can be concluded that investment decision has a positive and significant effect on the company value so that increasing investment decision will be followed by an increase in the company value. The expected investment provides a higher rate of return (internal rate of return) than the cost of capital, is considered being profitable. The higher the rate of profit generated from the investment activity of the company will increase the stock price of the company. The higher stock price has an effect on the increase of company value.

The research findings support signal theory (signaling theory) because investment decisions reflected by the MBVA are very important in an effort to increase the company value. It is because this type of investment will give a signal about the growth prospects of the company, in this case, the total growth of assets and the prospect of capitalization of the stock market value reflected in the growth of expected assets for the future.

According to the research conducted by Sartini and Purbawangsa (2014), Rakhimsyah, L. A., \& Gunawan, B. (2011), Fajriana and Priantinah (2016), Deviana and Fitria (2017), it is found that investment decision has positive and significant effect on company value. The same results are also obtained in the research, namely investment decision has a significant and positive impact on the company value. 
Dividend Policy Positively and Significantly Affects Company Value. The result of regression analysis obtained reveals that Hypothesis 3 (H_3) is accepted with marked positive regression coefficient. Thus, it can be concluded that dividend policy has positive and significant effect to company value so that increasing of dividend policy then will be followed by increase at company value.

The dividend policy is a financial decision made by the company whether the profit earned will be distributed to shareholders or held as retained earnings. Dividend policy often makes a conflict of interest between the management company and the investor. Bird in the hand theory states that investors are more interested in companies which pay dividends (Wiagustini, 2010). The dividend payout made by the company is considered being a positive signal by investors to invest, as investors prefer a definite return on their investment. The company that distributes dividends will attract investors to invest. With so many investors buying stocks, it will raise the stock price so that it increases the company value.

According to research by Anton (2016), Clementin and Priyadi (2016), Sartini and Purbawangsa (2014), Fenandar and Raharja (2012), it is explained that dividend policy has a positive and significant effect on company value. The same result is also found in research that dividend policy has significant and positive effect to company value.

Funding Decision Negatively and Significantly Affects Dividend Policy. The result of regression analysis obtained shows that Hypothesis $4\left(\mathrm{H}_{4} 4\right)$ is accepted with negative regression coefficient. Hence, it can be concluded that funding decision has negative and significant effect to dividend policy so that the decrease of fund decision will be followed by the increase dividend policy.

The negative effect of funding decision on dividend policy indicates that the trade-off theory (Modigliani \& Miller, 1963) applies to manufacturing companies listed on the Indonesia Stock Exchange (IDX) in 2013-2016, in which debt exceeding the optimum limit represents an excessively high debt and causes the company to have a risk of default higher so it leads to higher probability of bankruptcy. The more DER increases, the greater the debt burden the company pays, so it will lower the company's profit while profit is used to pay off the debt rather than pay dividends.

If the company's debt-equity ratio is high, then the company will be burdened with huge debt and agency fees, so the allocation of funds for dividend payout will be small. From this explanation, it can be seen that when the company's debt-equity ratio is high, then the dividend payout ratio will decrease.

The results of this study are in line with the results of research found by Fitriana and Pangestuti (2014) stating that funding decision has a significant and negative impact on dividend policy.

Investment Decision Positively and Significantly Affects Dividend Policy. The result of regression analysis obtained reveals that Hypothesis $6\left(\mathrm{H}_{-} 6\right)$ is accepted with positive regression coefficient. It can be concluded that investment decision has a positive and significant effect to dividend policy so that the increase of investment decision will be followed by the increase of dividend policy.

The company that has high IOS value also has high growth opportunities. High investment opportunities or IOS in the future make the company have a high growth rate. The company's management is willing to inform the public that the company has good prospects so that people are more interested in investing in the company. If the company can attract people to invest in the company, then the company will be easier to obtain additional capital to finance investment opportunities. The faster the growth rate of a company, the greater the need will be and to finance the growth of the company. The greater the need for future funding to finance its growth, the company usually prefers to hold earnings when it is paid as a dividend to shareholders by considering the limits of its cost. Therefore, it can be stated that the faster the growth rate of the company, the greater the required funds, the greater the chance to make a profit.

Acording to Sugiarto (2009) using data at company level, and using a combined six proxies to measure investment opportunity sets, it is found the results that are consistent with 
Smith and Watts (1992) research that company has DER and level lower dividend yield than non-growth company.

Gaver and Gaver also examine the IOS relationship with dividend policy by using DPR and dividend yield as dividend policy proxy. The results show that dividend yield has a significant negative relationship with IOS, but the IOS relationship with DPR is not significant. Jones and Sharma (2001) is consistent with Gaver and Gaver's research that growing company has DER and dividend yield which are lower than company which does not grow. Myers and Majluf (1984) argue that profitable company (high IOS) has a drive to pay relatively low dividends in order to obtain more internal funds to finance their investment projects.

The results of this study are in line with the results of research found by Deviana and Fitria (2017), Fitriana and Pangestuti (2014) stating that investment decisions have a significant and positive effect on dividend policy.

Dividend Policy is Able to Mediate Funding Decision towards Company Value. The previous explanation states that financial manager must choose a capital structure that maximizes the value of a company. Company should be able to find the appropriate financing mix to achieve optimal capital structure that directly affects the company's value (Ross et al. 2009). In terms of funding decision, the question that often arises is how the company gets business funds. Is the fund used should come from internal company or from external company? If used both, then what proportion is appropriate between internal funds (capital) and external funds (debt) to increase the value of the company?

In 1977, Ross claimed that a good company whose performance could signal to a high portion of its debt to its capital structure. The company's poor performance would not dare to use large amounts of debt because of its high bankruptcy probability (Sugiarto, 2009). According to Brigham and Houston (2007), the increase of debt can be interpreted by outsiders as the company's ability to pay its obligations in the future, so the increase in debt will be responded positively by the market.

In the previous hypothesis, it has also been explained that one financial decision will affect other financial decisions (Fama and French, 1998). Similarly, it is also same as funding decisions and dividend policies. Jensen and Meckling (1976) argue that if free cash flow is used to invest, the dividend payout ratio falls. A high debt-equity ratio can lower the dividend payout ratio. If the company's debt-equity ratio is high, then the company will be burdened with huge debt and agency fees, so the allocation of funds for dividend payout will be small.

Based on these explanations, it can be concluded that there is a significant effect of funding decision on dividend policy and company value. Thus, it is assumed that dividend policy can be an intervening variable between funding decision and company value.

Based on the results of this study, it is obtained that Hypothesis $5\left(\mathrm{H} \_5\right)$ is accepted. Dividend policy is able to mediate between variable of funding decision and variable of company value with sobel test. The results of this research are in line with result of research found by Fitriana and Pangestuti (2014) stating that dividend policy is able to mediate between the variables of financing decision and the variables of company value.

Dividend Policy is Able to Mediate Investment Decision towards Company Value. Investment decision is the decision that reflects future investment opportunities, ie through the introduction of new products or the expansion of old products, replacement of equipment or buildings, research and development, and exploration. The implication for companies is that company must plan to make investment decision through the introduction of new products or the expansion of old products, replacement of equipment or buildings, research and development.

Investment decision will have an effect on the company's performance over the long term while management has an enormous freedom in the use of company cash. By recognizing this, some researchers are trying to develop a signaling model in which capital investment is a signal that managers can use to show that company has high performance prospects reflected through company value. The investment opportunity that will cause future value will be greatly influenced by the investment made by the company, so that high IOS 
value is proven to have high company value in the current period and in the upcoming period.

The implication for company is that company must plan to make investment decision through the introduction of new products or the expansion of old products, replacement of equipment or building, research and development, and exploration. If the company is able to maximize its capability through these investments in generating profits in accordance with the amount of funds that are bound, it can increase the company value.

Based on the results of this research, it is obtained that Hypothesis $7\left(\mathrm{H}_{-} 7\right)$ is accepted. Dividend policy is able to mediate between investment decision variables and company value variables by using sobel test. The results of this research are in line with the research result found by Fitriana and Pangestuti (2014) stating that dividend policy is able to mediate between investment decision variables and company value variables.

\section{CONCLUSION AND SUGGESTIONS}

Some of the conclusions obtained from the results of this study are funding decision (DER), investment decision (MBVA), and dividend policy (DPR) have a positive and significant effect on company value (PBV). Funding Decision (DER) has a negative and significant effect on dividend policy (DPR). The investment decision (MBVA) has a significant positive effect on dividend policy (DPR). Dividend policy (DPR) is able to partially mediate funding decision variables (DER) and investment decision (MBVA) to corporate value variables (PBV).

The management party must be able to maintain the stability of profits, improve financial performance and company value for the sake of continuity and good prospects for the company in the future. Investors are more cautious in making investment decision in the manufacturing sector. Investors should be able to explore and learn more about the company's asset structure information so that investors know whether the company uses internal funds or external funds to finance the company's operations.

The future research agenda is expected to extend the year of research so that the results will be better. In addition, it is necessary to add a variable in future research so that the value of determination coefficient can be improved and the modeling becomes better.

\section{REFERENCES}

1. Anton, S. G. (2016). The impact of dividend policy on firm value. A panel data analysis of Romanian listed firms. Journal of Public Administration, Finance and Law, 10, 107-112.

2. Antwi, S., Mills, E. F. E. A., \& Zhao, X. (2012). Capital structure and firm value: Empirical evidence from Ghana. International Journal of Business and Social Science, 3(22).

3. Arifah, D. A., \& Roifah, S. (2013). The Effect Of Investment Decision, Funding Decision And Dividend Policy On Corporate Value . Journal of Economics.

4. Brigham, E. F., \& Houston, J. F. (2007). Fundamentals of financial management (Dasar-dasar Manajemen Keuangan). Engineering and Process Economics (Vol. 3). https://doi.org/10.1016/0377-841X(78)90069-4

5. Clementin, F. S., \& Priyadi, M. P. (2016). Pengaruh Keputusan Investasi, Pendanaan, Kebijakan Dividen dan Profitabilitas Terhadap Nilai Perusahaan. Jurnal IImu dan Riset Akuntansi, 5(4).

6. Cretu, A. E., \& Brodie, R. J. (2007). The influence of brand image and company reputation where manufacturers market to small firms: A customer value perspective. Industrial marketing management, 36(2), 230-240.

7. Deviana, N., \& Fitria, A. (2017). Pengaruh Profitabilitas dan Keputusan Investasi Terhadap Nilai Perusahaan Melalui Kebijakan Dividen. Jurnal IImu dan Riset Akuntansi, 6(3). 
8. Fajriana, A., \& Priantinah, D. (2016). Pengaruh Corporate Social Responsibility, Keputusan Investasi, Dan Struktur Modal Terhadap Nilai Perusahaan. Nominal, Barometer Riset Akuntansi dan Manajemen, 5(2).

9. Fama, E. F., \& French, K. R. (1998). Taxes, financing decisions, and firm value. The Journal of Finance, 53(3), 819-843

10. Fenandar, G. I., \& Raharja, S. (2012). Pengaruh keputusan investasi, keputusan pendanaan, dan kebijakan dividen terhadap nilai perusahaan (Doctoral dissertation, Fakultas Ekonomika dan Bisnis).

11. Fitriana, P. M., \& Pangestuti, I. R. D. (2014). Pengaruh Keputusan Investasi, Keputusan Pendanaan dan Profitabilitas terhadap Nilai Perusahaan: Kebijakan Dividen Sebagai Variabel Intervening (Studi Pada Perusahaan Manufaktur yang Terdaftar di BEl Periode 2009-2012) (Doctoral dissertation, Fakultas Ekonomika dan Bisnis).

12. Gordon, M. J. (1959). Dividends, earnings, and stock prices. The review of economics and statistics, 99-105.

13. Hasnawati, S. (2005). Dampak set peluang investasi terhadap nilai perusahaan publik di Bursa Efek Jakarta. Jurnal Akuntansi dan Auditing Indonesia, 9(2).

14. Husnan, S., (2008). Manajemen Keuangan Teori dan Penerapan Keputusan Jangka Panjang. Yogyakarta: BPFE.

15. Jensen, M. C., \& Meckling, W. H. (1976). Theory of the firm: Managerial behavior, agency costs and ownership structure. Journal of financial economics, 3(4), 305-360.

16. Jones, S., \& Sharma, R. (2001). The association between the investment opportunity set and corporate financing and dividend decisions: some Australian evidence. Managerial Finance, 27(3), 48-64.

17. Lintner, J. (1956). Distribution of incomes of corporations among dividends, retained earnings, and taxes. The American Economic Review, 46(2), 97-113.

18. Rakhimsyah, L. A., \& Gunawan, B. (2011). Pengaruh Keputusan Investasi, Keputusan Pendanaan, Kebijakan Dividen dan Tingkat Suku Bunga Terhadap Nilai Perusahaan. InFestasi, 7(1), 31-45

19. Ross, S. A., Westerfield, R. W., \& Jordan, B. D. (2009). Pengantar Keuangan Perusahaan. Jakarta: salemba empat.

20. Sartini, L. P. N., \& Purbawangsa, I. B. A. (2014). Pengaruh Keputusan Investasi, Kebijakan Deviden, serta Keputusan Pendanaan terhadap Nilai Perusahaan Manufaktur di Bursa Efek Indonesia. Matrik: Jurnal Manajemen, Strategi Bisnis Dan Kewirausahaan.

21. Sartono, A. (2001). Manajemen keuangan teori dan aplikasi. Yogyakarta: BPFE.

22. Smith Jr, C. W., \& Watts, R. L. (1992). The investment opportunity set and corporate financing, dividend, and compensation policies. Journal of financial Economics, 32(3), 263-292.

23. Sugiarto. (2009). Struktur Modal, Struktur Kepemilikan Perusahaan, Permasalahan Keagenan dan Informasi Asimetris. Graha IImu, Yogyakarta, Indonesia.

24. Supriyadi, E. (2014). SPSS+ Amos. Jakarta: In Media.

25. Wiagustini, N. L. P. (2010). Dasar-Dasar Manajemen Keuangan. Edisi Pertama. Denpasar: Udayana University. 